\title{
Effects of oestradiol and progesterone on secretion of gonadotrophins and health of first wave follicles during the oestrous cycle of beef heifers
}

\author{
E. J. Austin ${ }^{1}$, M. Mihm ${ }^{*}$, A. C. O. Evans' ${ }^{2}$ J. L. H. Ireland ${ }^{3}$, \\ J. J. Ireland ${ }^{3}$ and J. F. Roche ${ }^{1}$ \\ ${ }^{1}$ Faculty of Veterinary Medicine, Conway Institute of Biomolecular and Biomedical \\ Research, University College Dublin, Belfield, Dublin 4, Ireland; ${ }^{2}$ Faculty of Agriculture, \\ Conway Institute of Biomolecular and Biomedical Research, University College Dublin, \\ Belfield, Dublin 4, Ireland; and ${ }^{3}$ Molecular Reproductive Endocrinology Laboratory, \\ Department of Animal Science, Michigan State University, East Lansing, MI 48824, USA
}

Antral follicle development in cattle is initially FSH dependent and then LH dependent. The aim of the present study was to determine the effects of oestradiol- and progesterone-induced suppression of $\mathrm{FSH}$ and $\mathrm{LH}$ on growth and differentiation of first wave follicles. Cyclic heifers ( $n=45, n=6-10$ per group) received the following i.m. injections or treatments beginning $30 \mathrm{~h}$ after oestrus: (i) saline (controls); (ii) $0.75 \mathrm{mg}$ oestradiol benzoate (ODB); (iii) insertion of a progesterone-releasing intravaginal device (PRID) for $42 \mathrm{~h}$ (progesterone); (iv) $0.75 \mathrm{mg}$ oestradiol benzoate plus PRID (ODB plus progesterone); (v) $0.75 \mathrm{mg}$ ODB plus injection of $1 \mathrm{mg}$ Ovagen $^{\mathrm{TM}}$ at 33, 39 and $45 \mathrm{~h}$ after onset of oestrus (ODB plus FSH). In Expt 1, follicle development was monitored by ovarian ultrasonography once a day. In Expt 2, heifers were ovariectomized. Emergence of the first follicle wave and dominant follicle selection were delayed in ODB plus progesterone-treated heifers compared with controls. Interval to nadir FSH concentration was shorter in ODB-,

\section{Introduction}

Heifers usually have two or three waves of follicle growth during an oestrous cycle (Ireland et al., 2000). Reliable control of follicular waves in cattle is an important prerequisite for development of effective oestrous synchronization strategies that ultimately result in high pregnancy rates $(>65 \%)$ after artificial insemination (AI). Follicular emergence (that is, the first day of the oestrous cycle on which a follicle at least $4 \mathrm{~mm}$ in diameter is detectable by ovarian ultrasonography) and subsequent growth of follicles are dependent on an increase in

*Present address: University of Glasgow Veterinary School, Glasgow, UK

Email: edward.austin@ucd.ie progesterone- and ODB plus progesterone-treated heifers compared with controls. Frequency of LH pulses was unaffected in ODB- or ODB plus FSH-treated heifers, decreased in progesterone-treated heifers and further decreased in ODB plus progesterone-treated heifers. Intrafollicular oestradiol concentrations were lower in the largest follicle from ODB plus progesterone-treated heifers compared with control ( $66 \mathrm{~h}$ ) heifers, but follicle diameter and concentrations of insulin-like growth factor binding proteins (IGFBPs) and inhibin forms were unaffected. Treatment with ODB decreased follicular oestradiol concentration in smaller follicles in the cohort. It is concluded that growing cohort follicles are uniformly responsive to increased $\mathrm{FSH}$ concentration but differentially responsive to suppressed $\mathrm{FSH}$ and $\mathrm{LH}$ release, which is consistent with an LH-mediated survival advantage of the largest follicle in the cohort before cessation of the growth of remaining follicles in the cohort occurs. circulating FSH concentrations (Adams et al., 1992; Sunderland et al., 1994; Gong et al., 1996; Crowe et al., 1997). However, selection of a single dominant follicle depends on a decrease in serum FSH concentrations (Adams et al., 1992; Mihm et al., 1997). The subsequent fate of a selected dominant follicle is determined largely by LH pulse frequency (Kinder et al., 1996). In contrast, follicular emergence is considered to be independent of $\mathrm{LH}$, because follicle waves emerge during a variety of different reproductive states: for example, during periods of low LH pulse frequency in prepubertal heifers (Evans et al., 1994) and anoestrous cows (Stagg et al., 1995). Emerging follicles express mRNA for $\mathrm{LH}$ receptors in theca cells, and emerging dominant follicles express more $\mathrm{LH}$ receptor mRNA and contain more $\mathrm{LH}$ receptor protein relative to other follicles in the cohort (Stewart et al., 1996; Bao et al., 1997). These LH more may represent a pathway through which 
follicular growth could be fine-tuned by different LH pulse frequencies. However, the role of different patterns of $\mathrm{LH}$ in emerging follicle growth and differentiation has not been determined. A greater understanding of the precise roles of $\mathrm{FSH}$ and $\mathrm{LH}$ in emergence and selection is required to allow better hormonal treatments to be designed to manipulate follicular growth with predictable and precise results as part of an oestrous synchronization treatment.

Several studies have examined the effect of steroid administration during growth of the first follicle wave on follicle wave dynamics (Rajamahendran and Manikkam, 1994; Bo et al., 1995; O'Rourke et al., 1998). During the dominance phase of follicular growth, administration of progesterone reduces $\mathrm{LH}$ pulse frequency and intrafollicular concentrations of oestradiol, but increases the intrafollicular content of lower molecular mass insulin-like growth factor binding proteins (IGFBPs) and apoptosis of granulosa cells in dominant follicles (Manikkam and Rajamahendran, 1997). Thus, both dominant follicle growth and intrafollicular parameters can be altered by manipulation of LH pulse frequency. However, no studies to date have examined follicle growth and markers of follicle health when a steroid treatment is administered specifically to disrupt gonadotrophin secretion at the time of the peak in FSH concentrations that precedes emergence of the follicle wave. Hence, the specific aims of the present study were to determine the effects of oestradiol and progesterone treatments administered during the preemergence period of the first follicle wave of the bovine oestrous cycle on: (i) secretion of FSH and LH; (ii) growth of the first follicle wave; (iii) intrafollicular markers of follicle differentiation and health; and (iv) to determine any direct effects of oestradiol on FSH-induced follicle growth.

\section{Materials and Methods}

\section{Animals and treatments}

All heifers were kept in straw-bedded pens. Grass-silage was available ad libitum and each heifer received $2 \mathrm{~kg}$ of a $16 \%(\mathrm{w} / \mathrm{w})$ protein supplement each day. Oestrous cycles were synchronized using Norgestomet ear implants (Crestar ${ }^{\circledR}$; Intervet Ireland Ltd, Dublin) for 10 days with a single i.m. injection of $10 \mathrm{ml}$ of a $\mathrm{PGF}_{2 \alpha}$ analogue (Prosolvin ${ }^{\circledR}$; Intervet Ireland Ltd) 3 days before implant removal. Observations for oestrus began $24 \mathrm{~h}$ after implant removal and were performed every $3 \mathrm{~h}$ until the last heifer in the group showed oestrus. The day on which oestrous behaviour was first detected was designated as day 0 of the oestrous cycle. Thirty hours after oestrus was first detected, the heifers were allocated at random to one of the following treatment groups: (i) control: $3 \mathrm{ml}$ sterile saline injected i.m.; (ii) oestradiol benzoate (ODB): $0.75 \mathrm{mg}$ ODB (Intervet Ireland Ltd) in $3 \mathrm{ml}$ oil injected i.m.; (iii) progesterone: progesterone-releasing intravaginal device (PRID; Sanofi, Libourne) inserted for $42 \mathrm{~h}$; (iv) ODB plus progesterone: $0.75 \mathrm{mg}$ ODB injected i.m. plus PRID inserted for $42 \mathrm{~h}$; (v)
ODB plus FSH: $0.75 \mathrm{mg}$ ODB plus $1 \mathrm{mg}$ Ovagen $^{\text {TM }}$ both injected i.m. (Immuno-chemical Products Ltd, Auckland; $1 \mathrm{mg}$ Ovagen $^{\mathrm{TM}}$ is equivalent to $1 \mathrm{mg}$ NIADDK-oFSH-17) administered at 33, 39 and $45 \mathrm{~h}$ after the onset of oestrus to prevent the predicted decrease in FSH concentrations after oestradiol administration. Treatments began $30 \mathrm{~h}$ after oestrus (on day 1 of the oestrous cycle) because this is the expected time of the peak of the periovulatory increase in FSH concentrations, which usually immediately precedes emergence of the first wave of follicle growth (Austin et al., 2001). Hereafter, this period of follicle development, when treatments were initiated, will be referred to as preemergence. Withdrawal of progesterone treatment was scheduled to occur at $72 \mathrm{~h}$ after oestrus, equating to a PRID treatment duration of $42 \mathrm{~h}$. This timing was chosen so that the acute effects of increasing progesterone concentrations on gonadotrophins and follicle growth could be examined very early during follicular wave emergence.

All animal experimentation was performed in compliance with regulations set down by the BioMedical Centre, University College Dublin, and was licensed by the Department of Health and Children in accordance with the Cruelty to Animals Act (Ireland) 1897.

\section{Experiment 1: effect of $O D B$ and progesterone treatments on the growth of follicles, FSH-induced follicle growth and patterns of secretion of gonadotrophins during the first follicle wave}

Heifers were randomly allocated to treatment groups as follows: control $(n=7)$, ODB $(n=10)$, progesterone $(n=9)$, ODB plus progesterone $(n=9)$ and ODB plus FSH $(n=10)$. Beginning on day 0 of the oestrous cycle, a real time Bmode linear array ultrasound scanner with a $7.5 \mathrm{MHz}$ probe (Dynamic Imaging Concept 500, Livingstone) was used once a day to monitor growth of follicles $\geqslant 3 \mathrm{~mm}$ in diameter. The day of emergence of a new follicle wave was defined as the first day of the oestrous cycle on which two follicles not identified as belonging to a previous wave of follicular growth attained a diameter of $\geqslant 5 \mathrm{~mm}$. The first day of dominance of the first dominant follicle was defined by two criteria: (i) the first day of the oestrous cycle on which the largest follicle in a cohort of growing follicles achieved a diameter of $\geqslant 8.5 \mathrm{~mm}$; and (ii) the dominant follicle was $\geqslant 1.5 \mathrm{~mm}$ larger than the next largest follicle in the cohort.

Blood samples were collected by jugular venepuncture at $3 \mathrm{~h}$ intervals from $24 \mathrm{~h}$ after removal of the Norgestomet implant until $72 \mathrm{~h}$ after oestrus was detected, and then at $6 \mathrm{~h}$ intervals thereafter until emergence of the second follicle wave. An indwelling catheter was inserted into the jugular vein and blood samples were collected every $12 \mathrm{~min}$ for $8 \mathrm{~h}$ beginning $18-24 \mathrm{~h}$ after treatment, that is, on day 2 of the cycle, to determine the effect of treatments on $\mathrm{LH}$ pulse frequency and amplitude. Samples were maintained at room temperature for $1 \mathrm{~h}$, stored at $4^{\circ} \mathrm{C}$ for $24 \mathrm{~h}$, centrifuged at $1200 \mathrm{~g}$ for $20 \mathrm{~min}$, decanted and the 
serum was stored at $-20^{\circ} \mathrm{C}$ for subsequent hormone analysis.

\section{Experiment 2: effect of $O D B$ and progesterone treatments on follicle growth, $\mathrm{FSH}$-induced follicle growth and intrafollicular content of oestradiol, IGFBPS and inhibins}

Heifers were allocated to treatments as follows: control $(n=12)$; ODB $(n=7)$, progesterone $(n=6)$, ODB plus progesterone $(n=7)$ and ODB plus FSH $(n=7)$. Blood samples were collected by jugular venepuncture at $6 \mathrm{~h}$ intervals from $24 \mathrm{~h}$ after removal of the Norgestomet implant until ovariectomy. Ovariectomies were performed by colpotomy (Drost et al., 1992) at the following times: $36 \mathrm{~h}$ after onset of oestrus in six control heifers, hereafter referred to as FSH-peak controls; $66 \mathrm{~h}$ after oestrus in the remaining six control heifers, hereafter referred to as afterFSH-peak controls; and at $66 \mathrm{~h}$ after oestrus in all other treatment groups. The $36 \mathrm{~h}$ time point was selected because it is expected to be just after the peak of the periovulatory increase in serum FSH concentrations, when antral follicles start to grow, but should be before emergence of the first follicle wave detectable by ultrasonography. The $66 \mathrm{~h}$ time point was chosen because by this time serum FSH concentrations have decreased by at least $60 \%$ compared with the periovulatory peak concentration in control cycles and follicular wave emergence has typically occurred, as detected using ultrasonography. In addition, selection of the dominant follicle on the basis of size criteria (Sunderland et al., 1994) or deviation in growth rates (Ginther et al., 1996) has not yet taken place. After ovariectomy, follicles were dissected from each ovary and follicular fluid was recovered from the five largest follicles, centrifuged at $400 \mathrm{~g}$ for $1 \mathrm{~min}$ and frozen at $-80^{\circ} \mathrm{C}$.

\section{Hormone assays}

FSH. Serum FSH concentrations were determined using a previously validated radioimmunoassay (Crowe et al., 1997). The standard used was USDA-bFSH-B-1. Mean intra-assay ( $n=6$ samples) and interassay ( $n=23$ assays) coefficients of variation for a low $\left(8.1 \pm 0.3 \mathrm{ng} \mathrm{ml}^{-1}\right)$, medium (16.1 $\left.\pm 0.4 \mathrm{ng} \mathrm{ml}^{-1}\right)$ and high $\left(46.4 \pm 1.0 \mathrm{ng} \mathrm{ml}^{-1}\right)$ concentration sample were 13.0 and $16.3 \%, 10.1$ and $11.1 \%$, and 10.4 and $10.3 \%$, respectively. Sensitivity of the $\mathrm{FSH}$ assay was $2 \mathrm{ng} \mathrm{ml}^{-1}$.

$L H$. Serum LH concentrations were determined using a previously validated radioimmunoassay (Cooke et al., 1997). The standard used was NIH-bLH-B9. Mean intraassay ( $n=6$ samples) and interassay ( $n=13$ assays) coefficients of variation for a low $\left(3.4 \pm 0.1 \mathrm{ng} \mathrm{ml}^{-1}\right)$ and high $\left(12.9 \pm 0.2 \mathrm{ng} \mathrm{ml}^{-1}\right)$ concentration sample were 4.7 and $13.6 \%$, and 6.2 and $5.6 \%$, respectively.

Oestradiol. Oestradiol concentrations in follicular fluid were determined in samples diluted 1:100 with distilled water using a previously validated radioimmunoassay (Prendiville et al., 1995). Mean intraassay ( $n=6$ samples) and inter-assay ( $n=6$ assays) coefficients of variation for diluted follicular fluid samples with low $\left(0.63 \pm 0.03 \mathrm{ng} \mathrm{ml}^{-1}\right)$, medium $\left(2.12 \pm 0.08 \mathrm{ng} \mathrm{ml}^{-1}\right)$ and high (4.49 $\left.\pm 0.19 \mathrm{ng} \mathrm{ml}^{-1}\right)$ concentrations were 6.9 and $11.5 \%, 10.9$ and $9.3 \%$, and 10.4 and $10.6 \%$, respectively.

\section{Ligand blot analysis of IGFBPs and individual molecular mass forms of inhibin}

Relative quantities of IGFBP-2, $-3,-4$ and -5 in follicular fluid from the five largest follicles per heifer $(n=5$ heifers per treatment) were determined by ligand blot analysis, and quantified in relative density units per $25 \mu \mathrm{g}$ protein in follicular fluid as described by Jimenez-Krassel et al. (1999). The total density across all bands in the quality control lane was quantified and this was used to calculate a coefficient of variation for the IGFBP ligand blots. The coefficient of variation for total density of the QC lane between the 30 gels was $26.7 \%$. The amounts of the various molecular mass forms of inhibin were determined by immunoligand blot analysis in the presence of excess inhibin $\alpha$-subunit antibody and I ${ }^{125}$ - labelled $\alpha_{C}{ }^{1-26} \mathrm{Gly} \cdot$ Tyr using a previously validated procedure (Ireland et al., 1994). The total density across all bands in the QC lane was quantified and this was used to calculate a coefficient of variation for the inhibin ligand blots. The coefficient of variation for total density of the QC lane between the 30 gels was $27.0 \%$.

\section{Statistical analysis}

Means of serum FSH and LH parameters and follicle wave parameters were compared between the control and the different treatments in Expt 1 using ANOVA, with Fisher's least significant difference test as the post hoc comparison. Nadir FSH value after oestradiol treatment was the lowest concentration found in any FSH sample in the $48 \mathrm{~h}$ after the initial treatment at $30 \mathrm{~h}$ after oestrus. The characteristics of $\mathrm{LH}$ secretion at $24 \mathrm{~h}$ after treatment were determined using PC-PULSAR, the J. F. Gitzen and V. D. Ramirez (University of Illinois, Urbana, IL) modified adaptation of the pulsar programme as outlined by Merriam and Wachter (1984). Smoothing time was set at $300 \mathrm{~min}$ and the $\mathrm{G}$ values used for peak detection were 3.6, 2.4, 1.8, 1.4, and 1.0 for G1-G5, respectively. In Expt 2, oestradiol concentrations were log-transformed $\left(\log _{10}\right)$ before analysis, although actual mean values were used to construct Fig. 3. Means of intrafollicular oestradiol concentrations, amounts of IGFBPs and inhibin forms were compared between FSH-peak controls and after-FSH-peak controls by ANOVA. Similarly, means for after-FSH-peak controls and the ODB, progesterone, ODB plus progesterone, and ODB plus FSH treatments were also compared by ANOVA. $P<0.05$ was considered significant. 

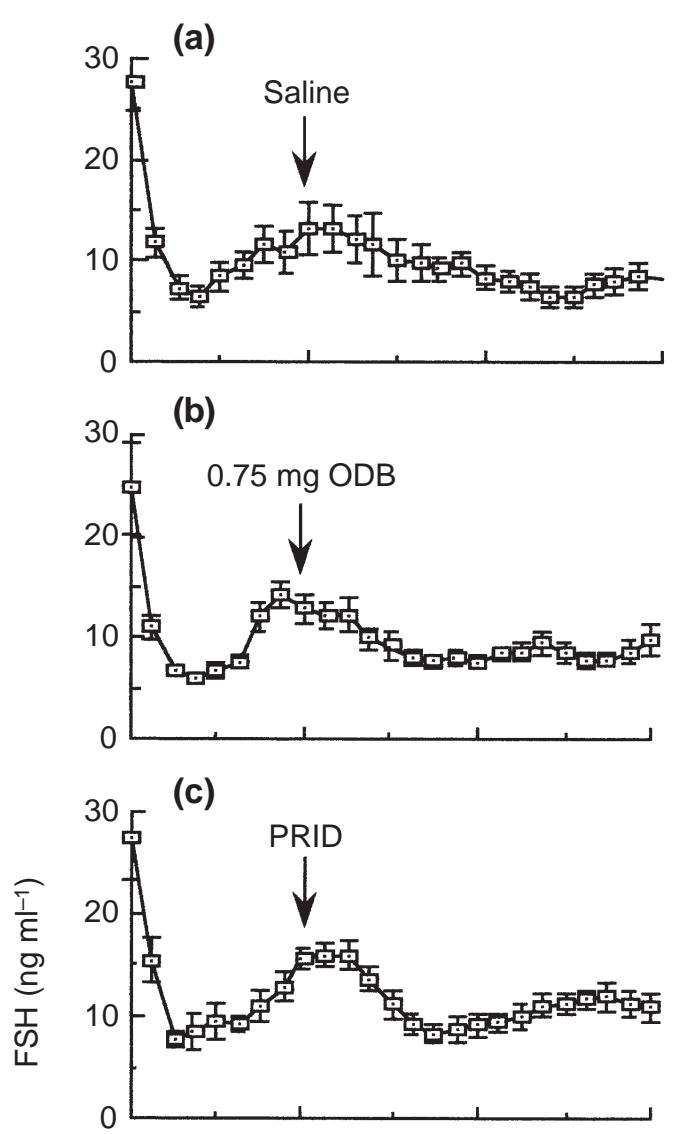

(d)

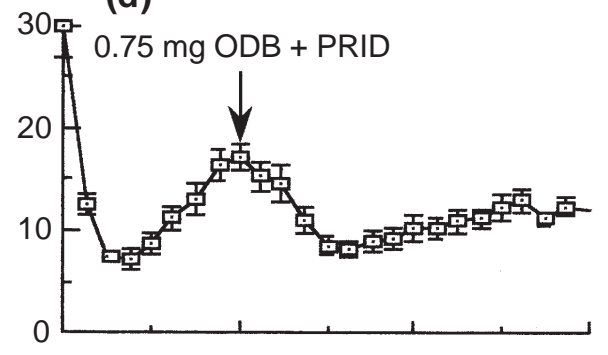

(e)

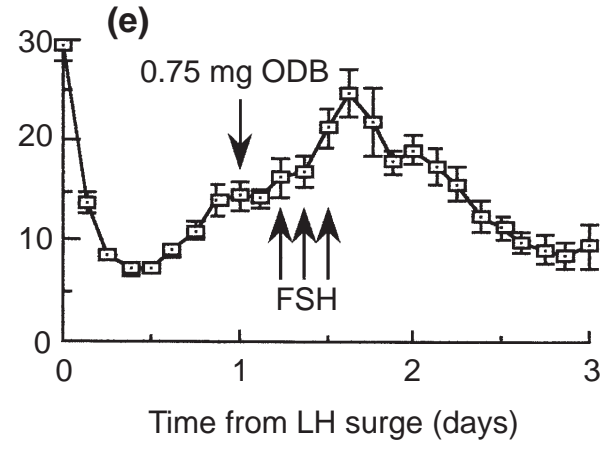

Fig. 1. Changes in serum concentrations of FSH during the first 3 days of the oestrous cycle from heifers in Expt 1. (a) Controls: saline-treated; (b) oestradiol benzoate: $0.75 \mathrm{mg}$ oestradiol benzoate (ODB); (c) progesterone: insertion of a progesteronereleasing intravaginal device (PRID); (d) ODB plus PRID: $0.75 \mathrm{mg}$ ODB and insertion of a PRID; and (e) ODB plus FSH: $0.75 \mathrm{mg}$ ODB plus injection of $1 \mathrm{mg}$ Ovagen $^{\mathrm{TM}}$ at 33, 39 and $45 \mathrm{~h}$ after onset of

\section{Results}

Experiment 1: effect of $O D B$ and short-term progesterone treatments on patterns of secretion of gonadotrophins during the first follicle wave, growth of emerging follicles and FSH-maintained follicle growth

All 45 heifers were observed in oestrus within 4 days of removal of the Norgestomet implant. Ovulation was detected in all heifers within 2 days of oestrus. Effects of hormone treatments beginning during pre-emergence on FSH and LH concentrations are shown (Figs 1 and 2, respectively). The effects of the hormonal treatments on serum $\mathrm{FSH}$ and $\mathrm{LH}$, and on subsequent growth of follicles in the first wave are described below.

$O D B$. After the periovulatory peak, nadir $\mathrm{FSH}$ concentrations were reached $10 \mathrm{~h}$ earlier $(P<0.05$, Table 1) and baseline $\mathrm{LH}$ concentrations were increased $(P<0.05)$ compared with controls on day 2 of the cycle (Table 2). The number of emerging follicles $\geqslant 3 \mathrm{~mm}$ in diameter did not differ from that of controls; however, the number of small follicles emerging during the second wave was nearly double that of controls $(P<0.05$, Table 3$)$. Maximum diameter of the first dominant follicle and day of emergence of the second follicle wave were similar to those in control heifers.

Progesterone. The interval to the nadir in serum FSH concentrations was reached $10 \mathrm{~h}$ earlier than in controls $(P<0.05$, Table 1$)$ and frequency of $\mathrm{LH}$ pulses was reduced $(P<0.05$, Table 2$)$. However, growth of first wave follicles was unaltered (Table 3) compared with controls.

$O D B$ plus progesterone. Nadir FSH concentrations were reached $12 \mathrm{~h}$ earlier $(P<0.05)$ and the rate of decrease in FSH concentrations was more than double that of controls (Table 1). In addition, LH pulses were almost completely abolished (Table 2). Emergence of the first follicular wave and first day of dominance were delayed $(P<0.05)$ and maximum size of the dominant follicle was lower $(P<0.05)$ compared with controls (Table 3). The number of follicles $\geqslant 3 \mathrm{~mm}$ in diameter emerging in either the first or second follicle wave did not differ from controls.

$O D B$ plus $F S H$. The interval from the preovulatory $\mathrm{LH}$ surge to the FSH peak and concentrations of FSH at the peak were doubled compared with controls $(P<0.05$, Table 1$)$. The interval from peak to nadir FSH concentrations was also increased $(P<0.05)$ by $10 \mathrm{~h}$. However, the effects of ODB treatment on $\mathrm{LH}$ secretion were not repeated when FSH was added (Table 2). The number of follicles $\geqslant 3 \mathrm{~mm}$ in diameter emerging in either the first or second follicle wave was unaltered. However, selection of the dominant follicle

oestrus. Values are mean \pm SEM ( $n=7-9$ per treatment). The arrow indicates the mean time of treatment in each treatment group. 
(a)

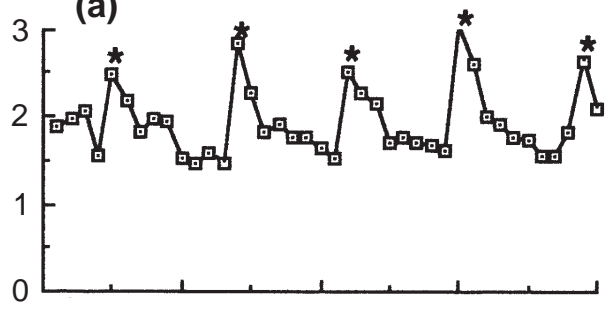

(b)

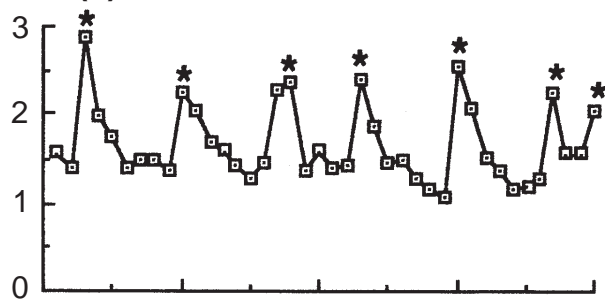

(c)

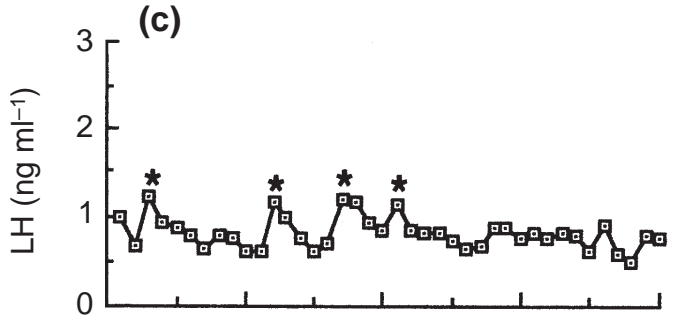

(d)
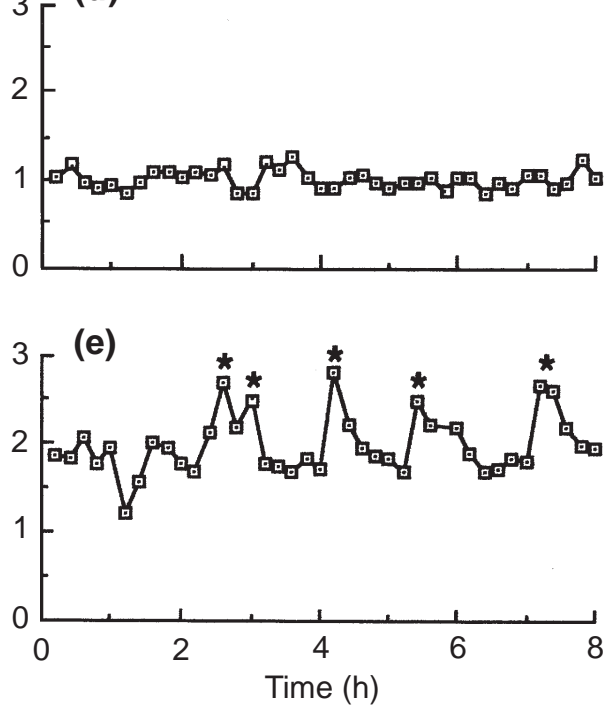

Fig. 2. Representative LH profiles from (a) control, (b) oestradiol benzoate (ODB)-, (c) progesterone-, (d) ODB plus progesteroneand (e) ODB plus FSH-treated heifers. Samples were collected every $12 \mathrm{~min}$ for $8 \mathrm{~h}$, commencing $18-24 \mathrm{~h}$ after treatment. Distinct pulses as identified using the PC-PULSAR programme are marked with an asterisk.

was delayed by 2.4 days, the maximum size of the dominant follicle was decreased $(P<0.05)$ and more $(P<0.05)$ follicles $\geqslant 5 \mathrm{~mm}$ in diameter were present on the first day of dominance compared with controls (Table 3 ). (a)

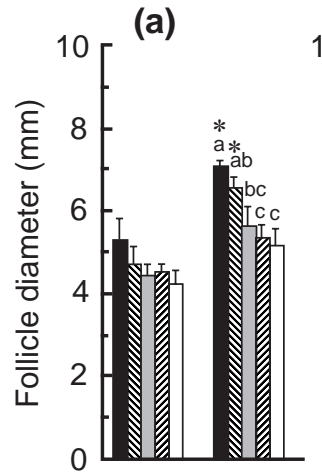

(c)

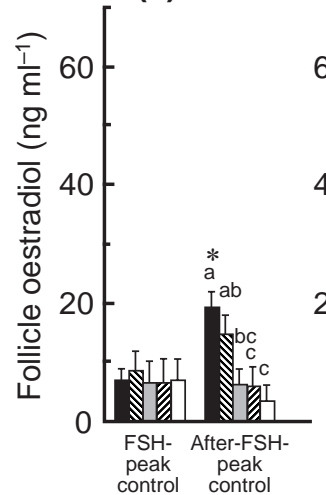

(b)

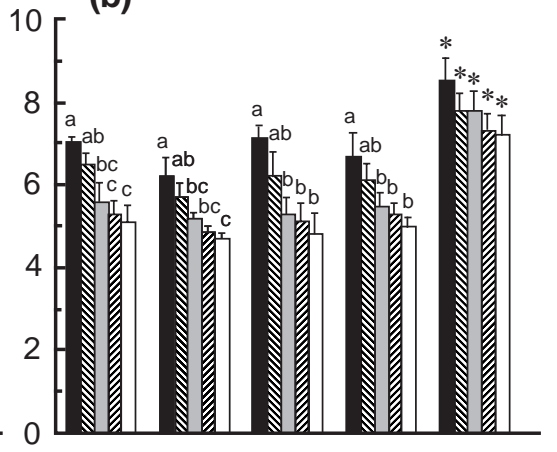

(d)

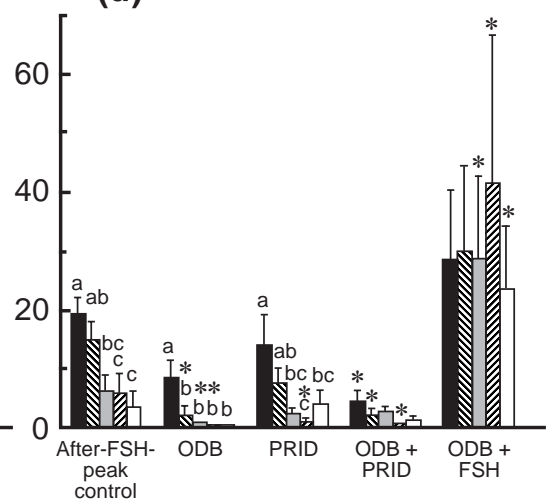

Fig. 3. (a,b) Mean follicle diameter and (c,d) follicular fluid

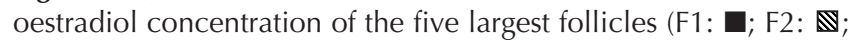
F3: $\square$; F4: $\mathbb{Z} ;$ F5: $\square$ ) per heifer recovered after ovariectomy from FSH-peak-controls, after-FSH-peak controls, oestradiol benzoate (ODB)-, progesterone (PRID)-, ODB plus PRID- and ODB plus FSH-treated heifers in Expt 2. Values are mean \pm SEM ( $n=7-9$ per treatment). *Indicates differences $(P<0.05)$ among similarly sizeranked follicles between $(\mathrm{a}, \mathrm{c}) \mathrm{FSH}$-peak controls and post-FSHpeak controls and (b,d) between post-FSH-peak controls and each treatment. ${ }^{a-c}$ Different superscripts indicate significant differences $(P<0.05)$ among follicles of different size rankings within a treatment group.

Experiment 2: effect of $O D B$ and progesterone and $O D B$ plus FSH given at pre-emergence on follicle wave growth and markers of intrafollicular health

Ovariectomy occurred $2 \pm 1 \mathrm{~h}$ and $32 \pm 2 \mathrm{~h}$ after the peak in serum FSH in FSH-peak controls and after-FSHpeak controls, respectively. The concentration of FSH at the time of ovariectomy was $95 \pm 5$ and $63 \pm 6 \%$ of its peak concentration in each of the two groups. In contrast, in ODB-, progesterone- and ODB plus progesterone-treated heifers, which were all ovariectomized at $32 \pm 2 \mathrm{~h}$ after the peak in $\mathrm{FSH}$, the concentration of $\mathrm{FSH}$ at ovariectomy was $42 \pm 3,42 \pm 4$ and $32 \pm 4 \%$ of its peak value in each of the three treatments. However, in ODB plus FSH-treated heifers, ovariectomy at $66 \mathrm{~h}$ after oestrus was only $9 \mathrm{~h}$ after the peak in FSH concentrations and the mean concentration of $\mathrm{FSH}$ at ovariectomy was similar to that in $\mathrm{FSH}$-peak controls at ovariectomy. 
Table 1. Effect of steroid treatments during the first follicle wave on systemic FSH concentrations in beef heifers in Expt 1

\begin{tabular}{|c|c|c|c|c|c|}
\hline \multirow[b]{2}{*}{ FSH parameters } & \multicolumn{5}{|c|}{ Treatment } \\
\hline & Control & ODB & Progesterone & ODB + progesterone & $\mathrm{ODB}+\mathrm{FSH}$ \\
\hline Number of heifers & 7 & 9 & 9 & 9 & 8 \\
\hline $\begin{array}{l}\text { Interval from LH surge to peak of } \\
\text { increase in } \mathrm{FSH}(\mathrm{h})\end{array}$ & $27.6 \pm 2.9^{\mathrm{a}}$ & $24.0 \pm 1.3^{a}$ & $27.0 \pm 0.9^{a}$ & $25.1 \pm 1.0^{\mathrm{a}}$ & $42.3 \pm 2.1^{b}$ \\
\hline Concentration of FSH at peak (ng ml-1) & $15.0 \pm 2.7^{a}$ & $15.8 \pm 1.2^{\mathrm{a}}$ & $17.7 \pm 1.2^{\mathrm{a}}$ & $19.3 \pm 1.3^{\mathrm{a}}$ & $30.2 \pm 2.0^{\mathrm{b}}$ \\
\hline Interval to nadir $(\mathrm{h})$ & $26.6 \pm 2.1^{a}$ & $16.3 \pm 1.2^{b}$ & $16.3 \pm 1.7^{b}$ & $14.3 \pm 1.7^{b}$ & $37.0 \pm 4.5$ \\
\hline Concentration of FSH at nadir $\left(\mathrm{ng} \mathrm{ml}^{-1}\right)$ & $5.6 \pm 0.8$ & $6.3 \pm 0.5$ & $6.8 \pm 0.6$ & $7.2 \pm 0.8$ & $6.9 \pm 1.1$ \\
\hline Rate of decrease in FSH $\left(\mathrm{ng} \mathrm{ml}^{-1} \mathrm{~h}^{-1}\right)$ & $0.4 \pm 0.1^{\mathrm{a}}$ & $0.6 \pm 0.1^{\mathrm{a}}$ & $0.7 \pm 0.1^{\mathrm{ab}}$ & $0.9 \pm 0.1^{b}$ & $0.7 \pm 0.1^{\mathrm{ab}}$ \\
\hline
\end{tabular}

Control: heifers received saline injected i.m.; ODB: $0.75 \mathrm{mg}$ oestradiol benzoate (ODB) was administered to the heifers; progesterone: heifers were treated with a progesterone-releasing intravaginal device (PRID); ODB + progesterone: heifers were treated with $0.75 \mathrm{mg}$ ODB and a PRID; and ODB + FSH: heifers received $0.75 \mathrm{mg}$ ODB plus three injections of $1 \mathrm{mg}^{\text {Ovagen }}{ }^{\mathrm{TM}}$ at 33, 39 and $45 \mathrm{~h}$ after oestrus. With the exception of the Ovagen ${ }^{\mathrm{TM}}$ injections all treatments were administered at $30 \mathrm{~h}$ after oestrus. PRIDs were removed $72 \mathrm{~h}$ after oestrus.

abc Values within rows with no common superscript are significantly different $(P<0.05)$.

Table 2. Effect of steroid treatments during the first follicle wave on pulsatility of LH measured in systemic circulation 18-24 h after treatment in Expt 1

\begin{tabular}{|c|c|c|c|c|c|}
\hline \multirow[b]{2}{*}{ LH parameters } & \multicolumn{5}{|c|}{ Treatment } \\
\hline & Control & ODB & Progesterone & ODB + progesterone & $\mathrm{ODB}+\mathrm{FSH}$ \\
\hline Number of heifers & 6 & 9 & 9 & 9 & 8 \\
\hline Number of pulses per $8 \mathrm{~h}$ & $5.2 \pm 0.5^{\mathrm{ab}}$ & $5.9 \pm 0.5^{\mathrm{a}}$ & $2.8 \pm 0.7^{c}$ & $0.7 \pm 0.4^{d}$ & $3.8 \pm 0.7^{b c}$ \\
\hline Amplitude $\left(\mathrm{ng} \mathrm{ml}^{-1}\right)$ & $0.8 \pm 0.2^{\mathrm{a}}$ & $1.2 \pm 0.1^{b}$ & $0.6 \pm 0.1 \mathrm{ac}$ & $0.4 \pm 0.1^{\mathrm{c}}$ & $0.7 \pm 0.1^{\mathrm{ac}}$ \\
\hline Baseline (ng ml-1) & $1.4 \pm 0.1^{\mathrm{ab}}$ & $2.7 \pm 0.4^{c}$ & $0.9 \pm 0.1^{\mathrm{a}}$ & $1.1 \pm 0.1^{\mathrm{a}}$ & $1.7 \pm 0.2^{b}$ \\
\hline Mean LH $\left(\mathrm{ng} \mathrm{ml}^{-1}\right)$ & $1.6 \pm 0.1^{\mathrm{ab}}$ & $3.1 \pm 0.4^{c}$ & $1.0 \pm 0.1^{\mathrm{a}}$ & $1.1 \pm 0.1^{\mathrm{a}}$ & $1.7 \pm 0.2^{b}$ \\
\hline
\end{tabular}

Treatments were as outlined in Table 1. ODB: oestradiol benzoate.

abc Values within rows with no common superscript are significantly different $(P<0.05)$.

Table 3. Effect of steroid treatments on growth of ovarian follicles as measured by ultrasonography during the first 12 days of the oestrous cycle in beef heifers in Expt 1

\begin{tabular}{|c|c|c|c|c|c|}
\hline \multirow[b]{2}{*}{ Ultrasound parameters } & \multicolumn{5}{|c|}{ Treatment } \\
\hline & Control & ODB & Progesterone & ODB + progesterone & $\mathrm{ODB}+\mathrm{FSH}$ \\
\hline Number of heifers & 7 & 10 & 9 & 9 & 9 \\
\hline $\begin{array}{l}\text { First follicle wave } \\
\text { Day of emergence } \\
\text { Number of follicles } \geqslant 3 \mathrm{~mm}\end{array}$ & $\begin{array}{l}2.0 \pm 0.2^{\mathrm{a}} \\
6.7 \pm 0.9\end{array}$ & $\begin{array}{l}3.0 \pm 0.4^{\mathrm{ab}} \\
8.2 \pm 1.0\end{array}$ & $\begin{array}{l}2.3 \pm 0.3^{a} \\
6.2 \pm 0.8\end{array}$ & $\begin{array}{l}3.7 \pm 0.6^{b} \\
5.4 \pm 0.7\end{array}$ & $\begin{array}{l}1.9 \pm 0.3^{\mathrm{a}} \\
8.2 \pm 1.1\end{array}$ \\
\hline $\begin{array}{l}\text { First dominant follicle } \\
\text { First day of dominance } \\
\text { Diameter }(\mathrm{mm}) \\
\text { Number of follicles* } \\
\text { Maximum diameter (mm) } \\
\text { Day of maximum size }\end{array}$ & $\begin{aligned} 4.7 & \pm 0.2^{\mathrm{a}} \\
9.5 & \pm 0.3 \\
1.2 & \pm 0.4^{\mathrm{a}} \\
12.5 & \pm 0.6^{\mathrm{a}} \\
6.8 & \pm 0.5\end{aligned}$ & $\begin{aligned} 6.1 & \pm 0.4^{\mathrm{ab}} \\
9.1 & \pm 0.2 \\
0.9 & \pm 0.3^{\mathrm{a}} \\
11.7 & \pm 0.6^{\mathrm{ab}} \\
8.8 & \pm 0.4\end{aligned}$ & $\begin{array}{c}5.0 \pm 0.3^{\mathrm{a}} \\
9.3 \pm 0.2 \\
1.3 \pm 0.4^{\mathrm{a}} \\
12.6 \pm 0.5^{\mathrm{a}} \\
9.0 \pm 0.6\end{array}$ & $\begin{aligned} 7.2 & \pm 0.7^{\mathrm{b}} \\
9.7 & \pm 0.2 \\
1.1 & \pm 0.1^{\mathrm{a}} \\
10.9 & \pm 0.4^{\mathrm{b}} \\
9.3 & \pm 0.7\end{aligned}$ & $\begin{aligned} 7.1 & \pm 0.7^{b} \\
9.4 & \pm 0.2 \\
3.5 & \pm 1.2^{b} \\
10.5 & \pm 0.4^{b} \\
8.8 & \pm 1.1\end{aligned}$ \\
\hline $\begin{array}{l}\text { Second follicle wave } \\
\text { Day of emergence* } \\
\text { Number of follicles } \geqslant 3 \mathrm{~mm}\end{array}$ & $\begin{array}{r}10.0 \pm 0.3 \\
4.3 \pm 0.1^{\mathrm{a}}\end{array}$ & $\begin{array}{c}10.8 \pm 0.5 \\
7.9 \pm 0.8^{b}\end{array}$ & $\begin{aligned} 10.4 & \pm 0.2 \\
6.1 & \pm 1.2^{\mathrm{ab}}\end{aligned}$ & $\begin{array}{l}9.9 \pm 0.2 \\
4.9 \pm 0.6^{a}\end{array}$ & $\begin{array}{r}10.4 \pm 0.6 \\
5.4 \pm 0.8^{a}\end{array}$ \\
\hline
\end{tabular}

Treatments were as outlined in Table 1; ODB: oestradiol benzoate.

*Number of follicles $\geqslant 5 \mathrm{~mm}$ in diameter, excluding the dominant follicle, on the first day of dominance.

One heifer in each of the ODB + progesterone and ODB + FSH groups did not select a dominant follicle.

abValues within rows with no common superscript are significantly different $(P<0.05)$. 


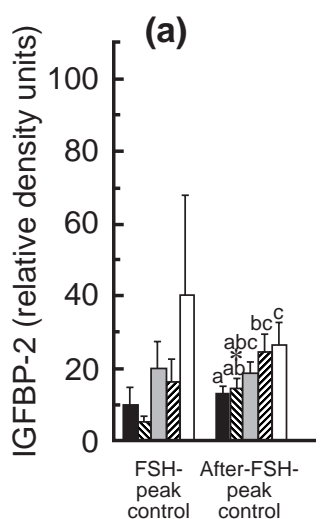

(b)
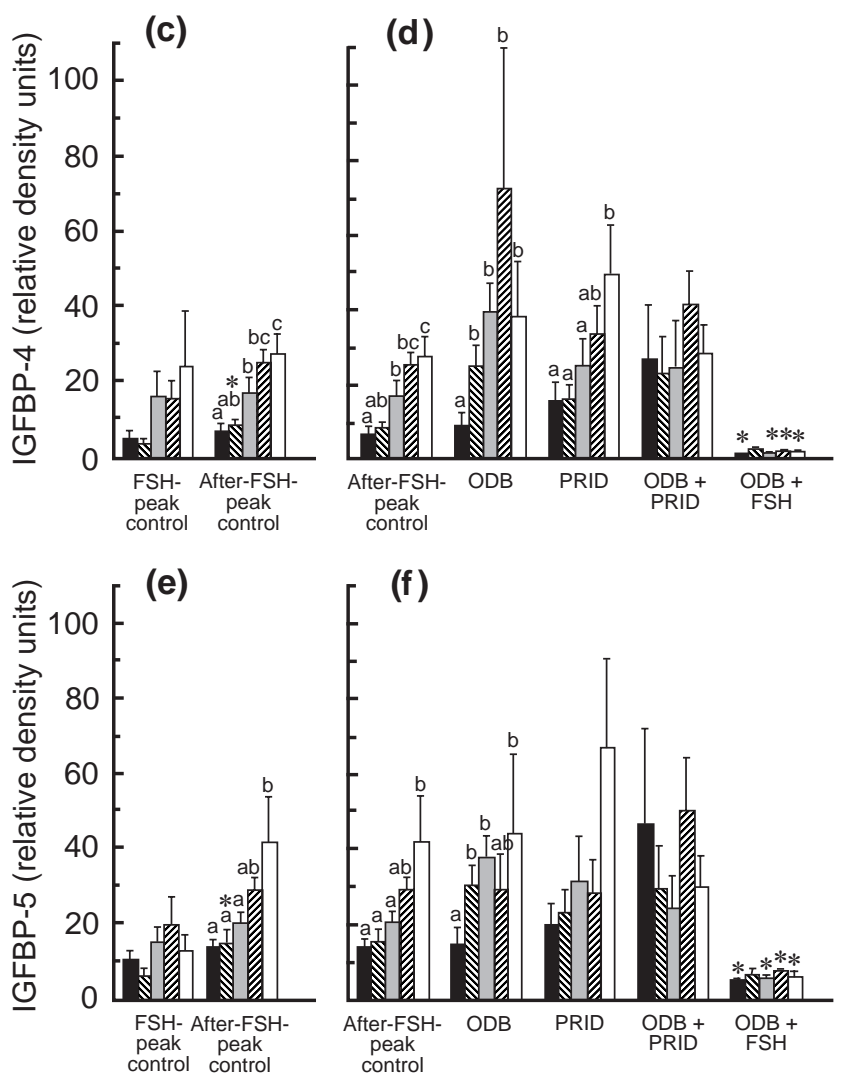

Fig. 4. Relative concentrations of insulin-like growth factor binding protein (IGFBP) (a,b) -2, (c,d) -4 and (e,f) -5 in follicular fluid of the five largest follicles (F1: $\mathbf{\square} ;$ F2: $\mathbb{Q} ;$ F3: $\square ;$ F4: $\mathbb{Z} ;$ F5: $\square$ ) per heifer recovered after ovariectomy from $\mathrm{FSH}$-peak controls, after-FSHpeak controls, oestradiol benzoate (ODB)-, progesterone (PRID)-, ODB plus PRID- and ODB plus FSH-treated heifers in Expt 2. Values are mean \pm SEM $(n=5) .{ }^{*}$ Indicates significant differences $(P<0.05)$ among similarly size-ranked follicles between $(\mathrm{a}, \mathrm{c}, \mathrm{e})$ FSH-peak controls and post-FSH-peak controls and (b,d,f) between post-FSH-peak controls and each treatment. ${ }^{a-c}$ Different superscripts indicate significant differences $(P<0.05)$ among follicles of different size rankings within a treatment group.

FSH-peak control versus after-FSH-peak control. In afterFSH-peak controls the two largest follicles, F1 and F2, were larger $(P<0.05)$ than the correspondingly ranked follicles in FSH-peak controls, but only the largest follicle (F1) had significantly higher $(P<0.05)$ oestradiol concentrations in follicular fluid (Fig. 3). Within the cohort of follicles in the after-FSH-peak controls, F1 was larger $(P<0.05)$ and contained more $(P<0.05)$ oestradiol in follicular fluid compared with F3, F4 and F5 (Fig. 3). Four different IGFBPs (IGFBP-2, -3, -4 and -5) and eight different molecular mass forms of $\alpha$-inhibin were identified in the follicular fluid of each follicle (precursors: $>160,110,77,58,49$ and $48 \mathrm{kDa}$; fully processed: $34 \mathrm{kDa}$; and $29 \mathrm{kDa}=$ inhibin $\alpha$ subunit). Relative quantities (relative density units of IGFBP$2,-4$ and -5 are shown (Fig. 4). Data for IGFBP-3 are not shown as no differences were found between follicles of different sizes, between FSH-peak and after-FSH-peak controls or between after-FSH-peak controls and steroid treatments. Data for only the 110 and $34 \mathrm{kDa}$ forms of inhibin are shown as representative of the precursors and fully processed forms, respectively (Fig. 5). In after-FSHpeak controls, both F1 and F2 contained increased $(P<0.05)$ content of $110 \mathrm{kDa} \alpha$-inhibin compared with the FSH-peak controls. In a comparison of FSH-peak controls and after-FSH-peak controls, similarly ranked follicles contained similar amounts of $34 \mathrm{kDa} \alpha$-inhibin, and IGFBPs $-2,-4$ and -5 , with the exception of F2, which contained more $(P<0.05)$ IGFBP-2, -4 and -5 (Fig. 4). Within the afterFSH-peak control cohort, the smallest follicles showed higher intrafollicular amounts of IGFBP $-2,-4$ and -5 compared with the F1 follicle.

$O D B$. After ODB treatment, the follicular diameter of F1-F5 was not different from those in the after-FSH-peak controls (Fig. 3). Intrafollicular oestradiol concentrations were also similar in $\mathrm{F} 1$ and $\mathrm{F} 5$, but were reduced $(P<0.05)$ in F2, F3 and F4 follicles. Amounts of the $110 \mathrm{kDa}$ form of inhibin were similarly lower $(P<0.05)$ in F2 and F4 compared with F2 and F4 in the after-FSH-peak controls (Fig. 4). Within the cohort there was also a reduction $(P<0.05)$ in the $110 \mathrm{kDa}$ form in F3, F4 and F5 compared with F1. Follicular contents of IGFBP-2, -4 and -5 were similar in correspondingly ranked follicles from after-FSHpeak controls and ODB heifers; however, differences between the largest and the other cohort follicles in IGFBP4 and -5 contents became more pronounced after ODB treatment.

Progesterone. Progesterone treatment did not alter follicle diameter (Fig. 3). Intrafollicular oestradiol concentration was lower $(P<0.05)$ in F4 compared with after-FSH-peak controls (Fig. 3) and F2 content of the $110 \mathrm{kDa}$ form of inhibin was also lower $(P<0.05$, Fig. 4$)$. After progesterone treatment, intrafollicular IGFBPs in $\mathrm{F} 1-\mathrm{F} 5$ were not different from those in F1-F5 in after-FSHpeak controls (Fig. 5).

ODB plus progesterone. The ODB plus progesterone treatment did not alter follicular size compared with the after-FSH-peak controls (Fig. 3). However, intrafollicular 
(a)

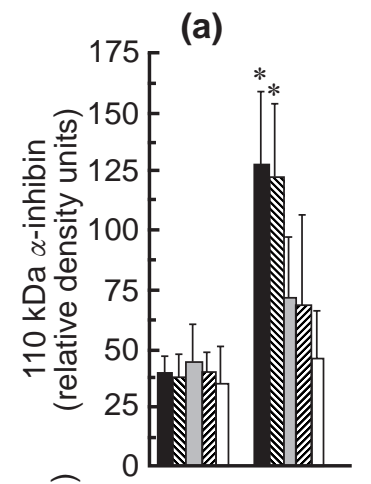

(b)

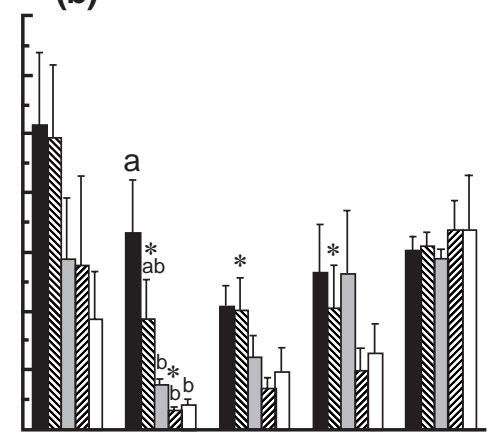

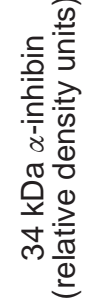

(c)
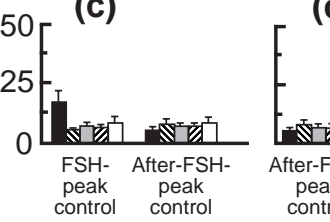

(d)

Fig. 5. Relative amounts of (a,b) 110 and (c,d) 34 kDa forms of $\alpha$ inhibin in follicular fluid of the five largest follicles (F1: $\mathbf{\square} ; \mathrm{F} 2: \mathbb{\mathbb { Q }}$; F3: $\square$; F4: $\mathbb{Z}$; F5: $\square$ ) per heifer recovered after ovariectomy from FSH-peak controls, after-FSH-peak controls, oestradiol benzoate (ODB)-, progesterone (PRID)-, ODB plus PRID- and ODB plus FSH-treated heifers in Expt 2. Values are mean \pm SEM $(n=5)$. *Indicates differences $(P<0.05)$ among similarly size-ranked follicles between $(\mathrm{a}, \mathrm{c})$ FSH-peak controls and post-FSH-peak controls and between (b,d) post-FSH-peak controls and each treatment. ${ }^{a b}$ Different superscripts indicate significant differences $(P<0.05)$ among follicles of different size rankings within a treatment group.

oestradiol concentrations in the F1, F2 and F4 follicles were lower $(P<0.05)$ compared with in the after-FSH-peak controls and there were no differences among F1-F5 follicles in intrafollicular oestradiol concentration after ODB plus progesterone treatment (Fig. 3). Content of the $110 \mathrm{kDa}$ form of inhibin in F2 was reduced $(P<0.05$, Fig. 4). After ODB plus progesterone treatment, intrafollicular IGFBPs in F1-F5 were not different from those in F1-F5 in after-FSH-peak controls and any differences in follicular content of IGFBP-2, -4 or -5 within the cohort were abolished (Fig. 5).

$O D B$ plus $F S H$. Follicle diameter for all five largest follicles was greater $(P<0.05)$ and intrafollicular oestradiol concentration was also higher in F3, F4 and F5 follicles when compared with correspondingly ranked follicles in the after-FSH-peak controls (Fig. 3). After ODB plus FSH treatment, all follicles within the cohort contained similar concentrations of oestradiol (Fig. 3), 110 and $34 \mathrm{kDa}$ inhibin forms (Fig. 4), and IGFBPs (Fig. 5). However, contents of IGFBP-2 were reduced $(P<0.05)$ in F2-F5 when compared with F2-F5 in after-FSH-peak controls after ODB plus FSH treatment. Similarly, IGFBP-4 and IGFBP-5 in F1, F3, F4 and F5 were lower $(P<0.05)$ when compared

with similarly ranked follicles in the after-FSH-peak controls (Fig. 5).

\section{Discussion}

In the present study, the effects of oestradiol, progesterone, oestradiol and progesterone, and oestradiol and FSH administered during pre-emergence of the first follicle wave, on patterns of secretion of gonadotrophins, follicle growth and alterations in intrafollicular markers of follicle differentiation in the first wave of follicle development during the oestrous cycle of beef heifers are reported for the first time. The most significant findings of this study were: (i) treatment with oestradiol plus progesterone, which induces almost complete short-term suppression of pulsatile secretion of $\mathrm{LH}$ and minor suppression of FSH during emergence of first wave follicles, retards dominant follicle growth and function; (ii) smaller cohort follicles are 'sensitive' to oestradiol-induced changes, including minor alterations in $\mathrm{FSH}$ secretion, whereas alteration of growth and oestradiol production of the largest cohort follicle was achieved only after the oestradiol plus progesterone combination treatment and was associated with partial suppression of FSH and almost complete abolition of $\mathrm{LH}$ pulsatility; and (iii) emergence of the next new wave of follicular growth is independent of early short-term alterations in patterns of gonadotrophin secretion and subsequent altered growth of first wave follicles.

Although the dependence of emerging follicles on FSH for their continued growth and development has been well documented (Adams et al., 1992; Mihm et al., 1997), the role of $\mathrm{LH}$ in development of emerging follicles has been largely discounted. However, emerging follicles express mRNA for LH receptors on theca cells (Bao et al., 1997) and early dominant follicles possess functional LH receptors (Stewart et al., 1996). The timing of transition from FSH dependence to $\mathrm{LH}$ responsiveness has proved controversial. Selection of the dominant follicle was reported to occur in the absence of differences in number of granulosa cell LH receptors as determined by radioreceptor assay (Bodensteiner et al., 1996) or differences in expression of mRNA for gonadotrophin receptors (Evans and Fortune, 1997). However, Bao et al. (1997) reported that follicular selection was associated with the initiation of expression of $\mathrm{LH}$ receptor mRNA in granulosa cells, and Stewart et al. (1996) determined that increased thecal binding of $\mathrm{LH}$ is an early event in selection of a dominant follicle. Similarly, Beg et al. (2001) found that increased expression of LH receptor mRNA in granulosa cells was an early event in the temporal sequence of changes associated with follicular deviation. Thus, selected follicles are likely to become very sensitive to alterations in LH. In the present study, administration of oestradiol and progesterone caused a reduction of the duration of the periovulatory increase in FSH concentrations, decreased secretion of LH during the early stages of the first follicle wave, delayed wave emergence, delayed onset of dominance and decreased follicular oestradiol concentration in the largest follicle in the cohort. 
In addition, the maximum diameter of dominant follicles was lower. Although the caveat that effects of the steroid treatments on follicular development may be mediated directly via ovarian steroid receptors must be accepted, these data provide compelling evidence for a role of $\mathrm{LH}$ in growth and oestradiol production of the largest follicles in a cohort emerging after the periovulatory increase in FSH concentration.

The ability of progesterone to terminate the growth of a dominant follicle and induce its atresia has been clearly demonstrated (Manikkam and Rajamahendran, 1997), and it presumably acts at least in part via suppression of $\mathrm{LH}$ pulses. Similarly, treatment of heifers with progesterone to suppress LH after the time of deviation in the rates of follicle growth between the dominant and next largest follicle led to a slight reduction in diameter of the dominant follicle and a sevenfold reduction in its follicular oestradiol concentration (Ginther et al., 2001). However, before deviation, when the largest follicle in control heifers was $8.7 \mathrm{~mm}$ in diameter, follicular fluid oestradiol concentration was unaffected by progesterone treatment (Ginther et al., 2001). In the present study, the largest follicle in the cohort contained decreased oestradiol concentration in its follicular fluid after the marked suppression of $\mathrm{LH}$ by oestradiol and progesterone when the follicle was $7 \mathrm{~mm}$ in diameter. The fact that suppression of follicular oestradiol occurred in a smaller follicle in the present study (compared with Ginther et al., 2001) may be due to the almost complete suppression of $\mathrm{LH}$ achieved in the present study after the combined oestradiol plus progesterone treatment.

Reduction of the duration of the periovulatory FSH surge after oestradiol treatment without any suppression of $\mathrm{LH}$ had no effect on oestradiol production in the largest follicle in the cohort, and progression of follicular selection and dominance was uninterrupted in these cows in Expt 1. However, smaller follicles in the cohort responded by decreasing oestradiol production. Such follicles are obviously more sensitive than the largest cohort follicle to the subtle suppression in FSH achieved after oestradiol treatment, thereby confirming their greater dependence on FSH for continued development. Austin et al. (2001) showed that at $66 \mathrm{~h}$ after oestrus, the time at which heifers were ovariectomized in Expt 2, a hierarchy of follicles already exists within the cohort in which largest size is usually coincident with highest follicular oestradiol concentrations. The results of the present study support a hypothesis of differential responsiveness already present among small follicles in an emerging cohort to changes in gonadotrophin secretion consistent with a hierarchy of responsiveness to changes in both $\mathrm{FSH}$ and $\mathrm{LH}$.

Despite the fact that the combination of oestradiol and progesterone caused suppression in LH pulse frequency and coupled with minor suppression of FSH resulted in retarded follicular growth and oestradiol production, follicular inhibin concentrations were unaffected in most cases. This finding is similar to that reported by Ginther et al. (2001) who showed that when heifers with a selected dominant follicle were treated with progesterone there was no effect on immunoreactive inhibin concentrations in follicular fluid of the dominant follicle, despite a reduction in follicle size and oestradiol concentration. One possible explanation for the relatively protected position of follicular inhibin in emerging cohort and dominant follicles is that the initial stimulation of production and subsequent maintenance of follicular fluid concentrations of inhibins may be differentially regulated. Austin et al. (2001) demonstrated that growth of F1 and F2 was accompanied by increased production of precursor inhibins. However, smaller follicles in the cohort did not increase production of precursor inhibins. In the present study, supplementary FSH administered just after the peak of the endogenous increase in FSH concentration and after exogenous oestradiol treatment caused all follicles to increase in size and to produce large amounts of oestradiol, but no alterations in inhibin production occurred. After the endogenous increase in $\mathrm{FSH}$, it appears that inhibin production may be near a maximum and additional FSH cannot enhance the initial effect. Suppression of FSH with exogenous ODB decreased precursor inhibin production in some of the smaller follicles in the cohort, but this effect was overcome by the addition of $\mathrm{FSH}$. Thus, the role of $\mathrm{FSH}$ in regulation of inhibin production may be dependent on whether the follicle has previously been stimulated to produce inhibin and whether the follicle is dependent on FSH for its continued growth.

In the present study, exogenous FSH treatment suppressed IGFBP-2, -4 and -5 in a similar way to that reported for FSH treatment without oestradiol (Mihm et al., 1997). Increased FSH concentration clearly prevents divergence in follicular development and associated biochemical alterations among the five largest follicles of the cohort. In contrast, during normal selection smaller follicles in the cohort show a decrease in follicular inhibins and an increase in IGFBP content due to their dependence on the decreasing supply of FSH (Mihm et al., 1997; Austin et al., 2001). As supplementary FSH suppressed IGFBPs but acute suppression of FSH and $\mathrm{LH}$ did not alter IGFBP production significantly, it is apparent that there are separate regulatory pathways for the downregulation of follicular IGFBPs in response to FSH and for the upregulation of IGFBPs in response to $\mathrm{FSH}$ withdrawal. Recent studies have uncovered evidence for IGFBP proteolytic activity in growing dominant follicles (Rivera et al., 2001;Spicer et al., 2001). Furthermore, Rivera and Fortune (2001) demonstrated that such proteolytic activity could be induced by FSH treatment, which leads to development of co-dominant follicles. The results of the present study demonstrate that the most marked or rapid effect achieved by the suppression of both gonadotrophins is suppression of oestradiol. This raises the possibility that oestradiol may be an important effector of cell survival and that its effects on inhibin and IGFBPs may be downstream events regulated by alterations in oestradiol secretion. Further support for this hypothesis was recently provided by Chamberlain and Spicer (2001) who reported no effect of 
FSH on production of IGFBPs by granulosa cell in vitro. It should also be considered that western ligand blot analysis may not have the required sensitivity to detect early subtle changes in inhibins and IGFBPs that may coincide with alterations in oestradiol production in response to the shortterm alterations in gonadotrophins achieved in this study.

Despite hormonally induced alterations in patterns of gonadotrophin secretion and alterations in follicle growth and differentiation during the first follicle wave, emergence of the second follicle wave was largely unaltered. Previous reports show that oestradiol plus a synthetic progestagen treatment during the first follicular wave terminates growth of the largest follicle, increases FSH concentration and advances emergence of the second follicle wave (Bo et al., 1994). The timing and extent of suppression in $\mathrm{FSH}$ and $\mathrm{LH}$ necessary to terminate growth of the entire cohort of developing follicles throughout a follicle wave is unknown. It appears that the short-term suppression of FSH to $<50 \%$ of its peri-ovulatory peak concentration in the present study was either too early during the wave, too short in duration or insufficient in magnitude to alter the pattern of follicular growth. The mechanisms regulating the timing of cessation of growth and subsequent loss of dominance during follicle waves are poorly understood, but are clearly important to understand, as mimicking the natural mechanism of loss of dominance would provide a means to terminate synchronously follicular growth as part of an oestrous synchronization regimen. Although the results presented in the present study are informative about the mechanisms that control cohort follicle growth in vivo, the mechanisms that trigger the end of dominance, which was a synchronous event in all cows in the present study, remain elusive.

In conclusion, the data presented in the present study demonstrate that the early growing cohort in the first follicle wave is responsive to oestradiol and progesterone treatment, which is associated with short-term alterations in FSH and LH concentrations. The most significant effect on follicular development was delayed selection of the dominant follicle and decreased oestradiol concentration in the largest follicle in the cohort. On the basis of our findings, it is concluded that growing cohort follicles are uniformly responsive to increased $\mathrm{FSH}$ concentrations but are differentially responsive to steroid treatment that suppressed $\mathrm{LH}$ release. These findings are consistent with an $\mathrm{LH}-$ mediated survival advantage of the largest follicle in the cohort before cessation of the growth of remaining follicles in the cohort is established.

This work was supported by the Irish Department of Agriculture and Food Stimulus Fund and by a USDA grant 94-37203-0720 and Research Excellence Funds to J. J. Ireland. The authors are grateful to Niamh Hynes, Gerry Calffey and Sheila NiCheallaigh for assistance in performing radioimmunoassays.

\section{References}

Adams GP, Matteri RL, Kastelic JP, Ko JCH and Ginther OJ (1992) Association between surges of follicle-stimulating hormone and the emergence of follicular waves in heifers Journal of Reproduction and Fertility 94 177-188

Austin EJ, Mihm M, Evans ACO, Knight PG, Ireland JLH, Ireland JJ and Roche JF (2001) Alterations in intrafollicular regulatory factors and apoptosis during selection of follicles in the first follicular wave of the bovine estrous cycle Biology of Reproduction 64 839-848

Bao B, Garverick HA, Smith GW, Smith MF, Salfen BE and Youngquist RS (1997) Changes in messenger ribonucleic acid encoding luteinizing hormone receptor, cytochrome P-450-side chain cleavage, and aromatase are associated with recruitment and selection of bovine ovarian follicles Biology of Reproduction 56 1158-1168

Beg MA, Bergfelt DR, Kot K, Wiltbank MC and Ginther OJ (2001) Follicular-fluid factors and granulosa-cell gene expression associated with follicle deviation in cattle Biology of Reproduction 64 432-441

Bo GA, Adams GP, Pierson RA, Tribulo HE, Caccia M and Mapletoft RJ (1994) Follicular wave dynamics after estradiol-17 $\beta$ treatment of heifers with or without a progestagen implant Theriogenology 41 1555-1569

Bo GA, Adams GP, Caccia M, Martinez M, Pierson RA and Mapletoft RJ (1995) Ovarian follicular wave emergence after treatment with progestagen and estradiol in cattle Animal Reproduction Science 39 193-204

Bodensteiner KJ, Wiltbank MC, Bergfelt DR and Ginther OJ (1996) Alterations in follicular estradiol and gonadotropin receptors during development of bovine antral follicles Theriogenology 45 499-512

Chamberlain CS and Spicer LJ (2001) Hormonal control of ovarian cell production of insulin-like growth factor binding proteins Molecular and Cellular Endocrinology 182 69-81

Cooke DJ, Crowe MA and Roche JF (1997) Circulating FSH isoform pattern during recurrent increases in $\mathrm{FSH}$ throughout the oestrous cycle of heifers Journal of Reproduction and Fertility 110 339-345

Crowe MA, Padmanabhan V, Hynes N, Sunderland SJ, Enright WJ, Beitins IZ and Roche JF (1997) Validation of a sensitive radioimmunoassay to measure serum follicle-stimulating hormone in cattle: correlation with biological activity Animal Reproduction Science 48 123-136

Drost M, Savio JD, Barros CM, Badinga L and Thatcher WW (1992) Ovariectomy by colpotomy in cows Journal of the American Veterinary Medicine Association $200337-339$

Evans AC and Fortune JE (1997) Selection of the dominant follicle in cattle occurs in the absence of differences in the expression of messenger ribonucleic acid for gonadotropin receptors Endocrinology $\mathbf{1 3 8}$ 2963-2971

Evans ACO, Adams GP and Rawlings NC (1994) Endocrine and ovarian follicular changes leading up to the first ovulation in prepubertal heifers Journal of Reproduction and Fertility 100 187-194

Ginther OJ, Wiltbank MC, Fricke PM, Gibbons JR and Kot K (1996) Selection of the dominant follicle in cattle Biology of Reproduction $\mathbf{5 5}$ 1187-1194

Ginther OJ, Bergfelt DR, Beg MA and Kot K (2001) Follicle selection in cattle: role of luteinizing hormone Biology of Reproduction $\mathbf{6 4}$ 197-205

Gong JG, Campbell BK, Bramley TA, Gutierrez CG, Peters AR and Webb R (1996) Suppression in the secretion of follicle-stimulating hormone and luteinizing hormone, and ovarian follicle development in heifers continuously infused with a gonadotropin-releasing hormone agonist Biology of Reproduction $\mathbf{5 5}$ 68-74

Ireland JJ, Mihm M, Austin E, Diskin MG and Roche JF (2000) Historical perspective of turnover of dominant follicles during the bovine estrous cycle: key concepts, studies, advancements, and terms Journal of Dairy Science 83 1648-1658

Ireland JLH, Good TEM, Knight PG and Ireland JJ (1994) Alterations in amounts of different forms of inhibin during follicular atresia Biology of Reproduction 50 1265-1276

Jimenez-Krassel F, Binelli M, Tucker HA and Ireland J (1999) Effect of longterm infusion with recombinant growth hormone-releasing factor and recombinant bovine somatotropin on development and function of dominant follicles and corpora lutea in Holstein cows Journal of Dairy Science 82 1917-1926

Kinder JE, Kojima FN, Bergfeld EGM, Wehrman ME and Fike KE (1996) Progestin and estrogen regulation of pulsatile $\mathrm{LH}$ release and 
development of persistent ovarian follicles in cattle Journal of Animal Science 74 1424-1440

Manikkam M and Rajamahendran R (1997) Progesterone-induced atresia of the proestrous dominant follicle in the bovine ovary: changes in diameter, insulin-like growth factor system, aromatase activity, steroid hormones, and apoptotic index Biology of Reproduction 57 580-587

Merriam G and Wachter KW (1984) Algorithms for the study of episodic hormone secretion. In Computers in Endocrinology pp 325-346 Eds D Rodbard and G Forti. Raven Press, New York

Mihm M, Good TEM, Ireland JLH, Ireland JJ, Knight PG and Roche JF (1997) Decline in serum follicle-stimulating hormone concentrations alters key intrafollicular growth factors involved in selection of the dominant follicle in heifers Biology of Reproduction 57 1328-1337

O'Rourke M, Diskin MG, Sreenan JM and Roche JF (1998) Effect of different concentrations of oestradiol administered during the first follicle wave in association with PRID insertion on follicle wave dynamics and oestrous response in beef heifers Journal of Reproduction and Fertility Abstract Series 21 Abstract 15

Prendiville DJ, Enright WJ, Crowe MA, Finnerty M, Hynes N and Roche JF (1995) Immunization of heifers against gonadotropin-releasing hormone: antibody titers, ovarian function, body growth, and carcass characteristics Journal of Animal Science 73 2382-2389

Rajamahendran R and Manikkam M (1994) Effects of exogenous steroid hormones on the dominant follicle maintained by a norgestomet implant in heifers Canadian Journal of Animal Science 74 457-464

Rivera GM and Fortune JE (2001) Development of co-dominant follicles in cattle is associated with a follicle-stimulating hormone dependent insulin-like growth factor binding-protein-4 protease Biology of Reproduction 65 112-118

Rivera GM, Chandrasekher YA, Evans ACO, Giudice LC and Fortune JE (2001) A potential role for insulin-like growth factor protein-4 proteolysis in the establishment of ovarian follicular dominance Biology of Reproduction 65 102-111

Spicer LJ, Chamberlain CS and Morgan GL (2001) Proteolysis of insulin-like growth factor binding proteins during preovulatory follicular development in cattle Domestic Animal Endocrinology 21 1-15

Stagg K, Diskin MG, Sreenan JM and Roche JF (1995) Follicular development in long-term anoestrous suckler beef cows fed two levels of energy post-partum Animal Reproduction Science 38 49-61

Stewart RE, Spicer LJ, Hamilton TD, Keefer BE, Dawson LJ, Morgan GL and Echternkamp SE (1996) Levels of insulin-like growth factor (IGF) binding proteins, luteinizing hormone and IGF-I receptors, and steroids in dominant follicles during the first follicular wave in cattle exhibiting regular estrous cycles Endocrinology 137 2842-2850

Sunderland SJ, Crowe MA, Boland MP, Roche JF and Ireland JJ (1994) Selection, dominance and atresia of follicles during the oestrous cycle of heifers Journal of Reproduction and Fertility 101 547-555

Received 8 January 2002

First decision 11 March 2002.

Revised manuscript received 5 July 2002.

Accepted 12 July 2002 